\title{
Impact of Diversified Agriculture Support Project (DASP) on Beneficiaries and Non-beneficiaries of District Allahabad (Uttar Pradesh), India
}

\author{
H.A. Malik ${ }^{1 *}$, B.N. Tripathi ${ }^{2}$, Nusrat $\mathrm{Jan}^{3}$, J.A. Quadri ${ }^{4}$, Sabiha Ashraf ${ }^{5}$ and F. Naqash ${ }^{6}$ \\ ${ }^{1}$ Directorate of Extension, SKUAST-Kashmir, India \\ ${ }^{2}$ Agri. Extension, AAI-DU Allahabad, India \\ ${ }^{3}$ DoA, Bandipora, Kashmir $(J \& K)$, India \\ ${ }^{4}$ DoAEx, FoA, SKUAST-K, India \\ ${ }^{5}$ College of Temperate Sericulture, SKUAST-K, India \\ ${ }^{6}$ DoAE\& HBM, SKUAST-K, India \\ *Corresponding author
}

\section{Keywords}

DASP, Impact, Technological backstopping, World Bank, Yield levels

Article Info

Accepted:

20 January 2019

Available Online:

10 February 2019
A B S T R A C T

The present study was conducted in District Allahabad, Uttar Pradesh State of India to evaluate the impact of Diversified Agriculture Support Project (DASP) launched under World Bank supported flagship programme on beneficiaries and non-beneficiaries. The major findings of the study revealed that majority of beneficiaries (41.33 percent) were in the age group of 40-50 years whereas the majority of non-beneficiaries (40.67 percent) belong to the age group of 50-60 years. The educational status of majority of beneficiaries (23.33 percent) was concentrated upto high school whereas majority of non-beneficiaries (32 percent) falls under illiterate category of educational standard. Further, majority of beneficiaries ( 45.33 percent) and non-beneficiaries ( 42.00 percent) had farming as their main occupation. It was also found that majority of the beneficiates $(60.00$ percent $)$ and non-beneficiaries (66.66 percent) had size of land holding upto 2 hectares. The data further reflected that almost $85-95 \%$ of the land holdings in both the cases belong to small and medium farmers. The results of the study further revealed that majority of beneficiaries had annual income above 3 lakhs whereas non- beneficiaries had an annual income of less than 3 lakhs. Regarding mass media exposure majority of the beneficiaries falls under medium level of mass media exposure, whereas non-beneficiaries fall under low level of mass media exposure. The results showed that the yield levels in respect of major Agricultural, Horticulture crops even milk per day per animal in case of beneficiaries was significantly much higher than non-beneficiaries thus indicating prominent impact of technological backstopping, demonstration, trainings, and supply of timely / quality inputs under DASP. The results of the study also concluded that cost of the production on account of different crops for beneficiaries had decreased and net returns of the produce had increased significantly due to efficient marketing strategies under DASP as compared to non- beneficiaries.

\section{Introduction}


Agriculture diversification creates opportunities for achieving higher and more stable rural incomes through the efficient use of resources and the exploitation of comparative advantage. Keeping it in view, a new and broader initiative in the form of Diversified Agriculture Support Project (DASP) was introduced by the Government of India for technology development and dissemination for all round development of agriculture and allied sectors in two States Uttar Pradesh and Uttaranchal with financial support from the World Bank. Uttar Pradesh, being largely agrarian in demographic and economic terms, no concept of development could ever be meaningful or worthwhile without focusing its attention on the development of Agriculture and allied sectors. Under this backdrop the Government launched Diversified Agriculture Support Project (DASP)with the objective to accelerate the growth of UP's diversified agriculture in relation to agro-ecological potential and market demand system with special emphasis on production systems that can benefit the rural poor. At the time of initiation of this project, contribution of Uttar Pradesh was 41.8 million tons in the national food grain production of 194.1 million tons. By the end of year 2015-16, the contribution of Uttar Pradesh was targeted at 44.01 million tons in the national food grain production of 252.22 million tones (Anonymous-2016). Social capital has positive impacts on agricultural production and income of the people (Yokoyama et al., 2003). Cluster approach and development of small organization was also one of the major focuses under DASP. Since these organizations undertake a great variety of strategies to increase their incomes through improved farm management and diversified income sources (Guyau, 2004). Therefore, the financial support and quantum of assistance provided under DASP, technological backstopping, critical inputs supplied, training and demonstration conducted under the programme offers a great scope to assess and evaluate the benefits of the programme and accordingly review the status as to what extent DASP has been successful in facilitating the technological backstopping and effective extension delivery system to the farmers. It was imperative, therefore, to know the impact of DASP and to determine the difference between beneficiaries and nonbeneficiaries in respect of pre-determined key performance indicators including production, yield, cost and income on Agriculture and allied sectors.

Under the above backdrop, the present study was carried out with the following specific objectives:

To assess the socio-economic profile of beneficiaries and non-beneficiaries of DASP in the sample areas

To assess the impact of DASP on beneficiaries and non-beneficiaries with respect to Agriculture, Horticulture and Animal Husbandry

\section{Materials and Methods}

Uttar Pradesh consists of 32 districts in which Allahabad district was selected purposively for the study. In Allahabad district, 5 blocks were under DASP from which two villages from each block were randomly selected for the study. The respondents were sixty in each block covering five blocks with 10 villages; total size of sample consists of 300 respondents' with 150 beneficiaries and 150 non- beneficiaries. Stratified random sampling procedure was adopted for the study. Keeping in view the purpose and objectives of the study, information and opinions were obtained firstly on pilot basis followed through personal interview with the help of well-designed pre-structured schedule. 
The data collected from beneficiaries and non-beneficiaries were then tabulate, analyzed in light of pre- determined objectives for the present study.

\section{Results and Discussion}

To assess the socio-economic profile of beneficiaries and non-beneficiaries of DASP in the sample areas

\section{Socio-economic factors (variables)}

Age, education, occupation, size of land holding, annual income were chosen as socioeconomic factors, in addition some communication variable like mass media exposure were also taken for the present study to make it more comprehensive and result oriented. A gist of the results of these variables thus obtained is summarized under Table 1.

\section{Description on the socio -economic factors}

\section{Age}

Table 1 reveals that that the percentage in respect of age of beneficiaries as well as nonbeneficiaries goes on increasing as we go from lower to higher intervals. The maximum numbers of beneficiaries 41.33 percent were concentrated in the age group of 40-50 years where as the maximum number of nonbeneficiaries 40.67 percent falls under the age group of 50-60 years. The figure also shows that only 5.33 percent of beneficiaries and 4.00 percent of non-beneficiaries were concentrated under the age group of 20-30 years.

\section{Education}

The table reveals that in case of beneficiaries 18 percent of the respondents were illiterate followed by 16 percent who had educational status upto middle and 23.33 percent upto high school. Also there were 12.67 percent of respondents who had educational standard upto intermediate followed by 8 percent as graduation level of educational standard and 3.33 percent who had educational attainment above graduation in case of beneficiaries.

However, on the other hand, the educational standard of non-beneficiaries comprises of about 32 percent who were illiterate followed by 24 percent upto primary and 20.67 upto middle and 11.33 percent who had educational attainment upto high school. Also there were 8.00 percent of respondents who had educational standard upto intermediate followed by 3.33 percent as graduation level of educational standard and 0.67 percent who had educational attainment above graduation in case of non- beneficiaries.

\section{Occupation}

The results shown under Table 1 reveals that 26.67 percent of beneficiaries and 34.00 percent of the non-beneficiaries were engaged in faming and labour followed by 45.33 percent of beneficiaries and 42.00 of nonbeneficiaries who were engaged in faming.

About 13.33 percent of beneficiaries and 18.00 percent of non-beneficiaries were engaged in farming \& caste occupation followed by 9.33 percent of beneficiaries and 4.00 percent non-beneficiaries who had farming \& service as their occupation.

Only 5.33 percent of the beneficiaries and 2.00 percent non-beneficiaries had their occupation as farming $\&$ business.

\section{Size of land holding}

Looking at Table 1, the data reveals that 60.00 percent of the beneficiaries and 66.66 percent of the non-beneficiates had their size of land holding upto 2 hectares followed by 26.66 percent of the beneficiaries and 30.00 
percent of the non-benefactress who had their size of land holding ranging from 2-4 hectares. Similarly, 13.33 percent of the beneficiaries and only 3.33 percent of the non-beneficiaries had above 4 hectares as their size of land holding.

\section{Annual income}

Regarding annual income, Table 1 reveals that 9.33 percent of the beneficiaries and 20.67 percent of the non-beneficiaries had an annual income upto rupees one lakh fifty thousand followed by 28.00 percent of the beneficiaries and 44.67 percent of the nonbeneficiaries who had an annual income ranging between one lakh fifty thousand to three lakh rupees, also about 62.67 percent of the beneficiaries and 34.67 percent of the non-beneficiaries had more than three lakh rupees as their annual income.

\section{Mass media exposure}

It is evident from the Table 1 that 18.00 percent of the beneficiaries and 46.00 percent of non-beneficiaries had low mass media exposure followed by 53.33 percent of the beneficiaries and 42.67 percent of nonbeneficiaries who had medium level of mass media exposure, also 28.67 percent of beneficiaries and 11.33 percent of the nonbeneficiaries had high mass media exposure.

To assess the impact of DASP on beneficiaries and non-beneficiaries with respect to Agriculture, Horticulture and Animal Husbandry.

In order to assess the potential impact through project interventions related to Agriculture, Horticulture, Animal Husbandry between beneficiaries and non-beneficiaries, this objective was formulated to analyze and compare various key performance indicators undertaken in response to technological interventions yield gaps and cost benefit analysis.

Impact of DASP interventions on Agriculture (Crop Husbandry)

Regarding Agriculture (Crop Husbandry), the average yield of important crops were obtained and estimated. Since yield is the ultimate indicator to assess the production of several improved practices with respect to the technology dissemination, the difference between the average production of these crops among beneficiaries and non-beneficiaries were also calculated. Cost estimation and net returns on account of Agriculture (Crop Husbandry) were also calculated to obtain a broader picture of impact of the intervention. The yield data and cost estimation thus obtained are summarized at Table 2 (a) and Table 2 (b) respectively.

The data indicated under Table 2 (a) reveals that there was a wide yield gap between beneficiaries AND non-beneficiaries in respect of yield of major crops. The figures reveals that the average production of paddy in respect of beneficiaries was $27 \mathrm{Q} / \mathrm{ha}$ whereas it is $20 \mathrm{Q} / \mathrm{ha}$ in case of nonbeneficiaries thus there was a yield gap of 7 $\mathrm{Q} / \mathrm{ha}$. The average production of wheat among the beneficiaries was $32 \mathrm{Q} / \mathrm{ha}$ while it remains at $24 \mathrm{Q} / \mathrm{ha}$ with respect to nonbeneficiaries leading to a yield difference of about $8 \mathrm{Q} / \mathrm{ha}$. The situation was not different when it comes to Maize were the average production of beneficiaries was $19 \mathrm{Q} / \mathrm{ha}$ whereas it was $13 \mathrm{Q} / \mathrm{ha}$ in case of nonbeneficiaries thus leading to a difference of 6 $\mathrm{Q} / \mathrm{ha}$. Similarly, the average production of beneficiaries in case of Potato was $252 \mathrm{Q} / \mathrm{ha}$ against $215 \mathrm{Q} /$ ha in case of non-beneficiaries thus a yield gap of almost $37 \mathrm{Q} / \mathrm{ha}$ was observed between beneficiaries and nonbeneficiaries. The figures with respect to Mustard and Arhar reveals that there was a yield gap between the beneficiaries and nonbeneficiaries upto the extent of $4 \mathrm{Q} / \mathrm{ha}$ and 5 
Q/ha respectively. It explains that yield level in respect of major crops in case of beneficiaries was comparatively much higher than non-beneficiaries thus clearly shows the impact of technologies under DASP.

For the purpose of comparing the project benefits, the crop budget estimates were compared between beneficiaries \& nonbeneficiaries. The data in Table 2(b) shows that average production of beneficiaries with respect of Paddy was $27 \mathrm{Q} /$ ha which gave rise to a gross income of Rs. 15,120/= per hectare at a price of Rs 560 per quintal, an average expenditure of Rs. 8500/= per hectare was incurred, thus the net amount left with the beneficiaries was upto the tune of Rs. 6620/= per hectares, the same procedure when applied for non-beneficiaries, the net returns remains at Rs. 2500/= per hectare thus showing that there was a remarkable difference in respect of net income generated by the beneficiaries and non-beneficiaries in case of Paddy. Similarly, the average production of beneficiaries with respect of Wheat was $32 \mathrm{Q} / \mathrm{ha}$ which gave rise to a gross income of Rs 18,560/= per hectare at a price of Rs 580 per quintal, an average expenditure of Rs. 9500/= per hectare was incurred, thus the net amount received by the beneficiaries was upto the sum of Rs. 9060/= per hectares, the same procedure was repeated for nonbeneficiaries, the net returns remains at Rs 4020 /= per hectare thus again showing that there was a significant difference in respect of net income generated by the beneficiaries and non-beneficiaries in case of Wheat. Likewise in case of Potato, the average production of beneficiaries with respect of Potato was $252 \mathrm{Q} / \mathrm{ha}$ which gave rise to a gross income of Rs. 70,560/= per hectare at a price of Rs 280 per quintal, an average expenditure of Rs $22,000 /=$ per hectare was incurred, thus the net amount received by the beneficiaries was upto the sum of Rs. 48,560/= per hectares, however, the crop estimation in respect of Potato for non-beneficiaries shows the net returns after deducting the expenditure remains at Rs. 37,200/= per hectare leading to a significant difference in respect of net income generated from Potato cultivation by the beneficiaries and non-beneficiaries.

The difference in respect of net income between beneficiaries and non-beneficiaries was mainly due to development and adoption of improved technologies, admirable extension services including trainings, demonstrations and timely availability of critical inputs provided to beneficiaries under DASP.

\section{Impact of DASP interventions on Horticulture (Vegetable production)}

The principal horticultural crops (vegetables) grown in the sample areas were taken for the purpose and average yield for these vegetables grown by beneficiaries and nonbeneficiaries were obtained and estimated. Further, the yield gaps were also calculated to measure extent of the impact of technologies and services provided to beneficiaries under DASP. The same is summarized under Table 3.

The data with respect to yield of horticulture crops (vegetables) given in the Table 3 shows that there was a wide yield gap between beneficiaries \& non-beneficiaries. The figures reveals that the average production of Tomato in respect of beneficiaries was $248 \mathrm{Q} / \mathrm{ha}$ against $212 \mathrm{Q} / \mathrm{ha}$ in case of non-beneficiaries thus there was a yield gap of $36 \mathrm{Q} / \mathrm{ha}$. The average production of Brinjal among the beneficiaries was $245 \mathrm{Q} /$ ha against $210 \mathrm{Q} / \mathrm{ha}$ with respect to non-beneficiaries leading to a yield difference of about $35 \mathrm{Q} / \mathrm{ha}$. Similarly, the average production of beneficiaries in case of Onion was $160 \mathrm{Q} /$ ha against $120 \mathrm{Q} / \mathrm{ha}$ in case of non-beneficiaries thus a yield gap of almost $40 \mathrm{Q} / \mathrm{ha}$ was observed between beneficiaries and non-beneficiaries. 
Table.1 Socio-personal and economic factors (variables) of respondents

$(\mathrm{N}=300)$

\begin{tabular}{|c|c|c|c|c|c|c|}
\hline \multirow[t]{2}{*}{ S.No } & \multirow[t]{2}{*}{ Variables } & \multirow[t]{2}{*}{ Categories } & \multicolumn{2}{|c|}{ Beneficiaries(150) } & \multicolumn{2}{|c|}{ Non-beneficiaries $(150)$} \\
\hline & & & f & $\%$ & f & $\%$ \\
\hline \multirow[t]{5}{*}{1} & \multirow[t]{5}{*}{ Age (Yrs) } & $20-30$ & 08 & 5.33 & 6 & 4.00 \\
\hline & & $30-40$ & 22 & 14.67 & 14 & 9.33 \\
\hline & & $40-50$ & 72 & 41.33 & 57 & 38.00 \\
\hline & & $50-60$ & 37 & 24.67 & 61 & 40.67 \\
\hline & & $60 \&$ above & 21 & 14.00 & 12 & 8.00 \\
\hline \multirow[t]{7}{*}{2} & \multirow[t]{7}{*}{ Education } & Illiterate & 27 & 18.00 & 48 & 32.00 \\
\hline & & Upto Primary & 24 & 16.00 & 36 & 24.00 \\
\hline & & Upto Middle & 28 & 18.67 & 31 & 20.67 \\
\hline & & Upto High School & 35 & 23.33 & 17 & 11.33 \\
\hline & & Upto Intermediate & 19 & 12.67 & 12 & 8.00 \\
\hline & & Upto Graduation & 12 & 8.00 & 05 & 3.33 \\
\hline & & Above Graduation & 05 & 3.33 & 01 & 0.67 \\
\hline \multirow[t]{5}{*}{3} & \multirow[t]{5}{*}{ Occupation } & Farming \&labour & 40 & 26.67 & 51 & 34.00 \\
\hline & & Farming & 68 & 45.33 & 63 & 42.00 \\
\hline & & $\begin{array}{l}\text { Farming \& Caste } \\
\text { Occupation }\end{array}$ & 20 & 13.33 & 27 & 18.00 \\
\hline & & Farming \&Service & 14 & 9.33 & 6 & 4.00 \\
\hline & & Farming \& business & 8 & 5.33 & 3 & 2.00 \\
\hline \multirow[t]{3}{*}{4} & \multirow[t]{3}{*}{ Size of land holding (ha) } & Upto 2 hectares & 90 & 60.00 & 100 & 66.66 \\
\hline & & 2-4 hectares & 40 & 26.66 & 45 & 30.00 \\
\hline & & Above 4 hectares & 20 & 13.33 & 5 & 3.33 \\
\hline \multirow{3}{*}{5} & \multirow{3}{*}{ Annual income (Rs) } & Upto 1,50000 & 14 & 9.33 & 31.00 & 20.67 \\
\hline & & 1,50000 to 3,00000 & 42 & 28.00 & 67.00 & 44.67 \\
\hline & & Above 3,00000 & 94 & 62.67 & 52.00 & 34.67 \\
\hline \multirow{3}{*}{6} & \multirow{3}{*}{ Mass media exposure } & Low $(0-5)$ & 27 & 18.00 & 69.00 & 46.00 \\
\hline & & Medium (5-10) & 80 & 53.33 & 64.00 & 42.67 \\
\hline & & High (10-15) & 43 & 28.67 & 17.00 & 11.33 \\
\hline
\end{tabular}

Table.2a Yield of major crops of respondents and the yield gap between respondents

\begin{tabular}{|l|l|c|c|c|}
\hline S.No & Crop & Beneficiaries & Non-Beneficiaries & Difference \\
\cline { 3 - 5 } & & Average yield $(\mathrm{Q} /$ ha. $)$ & Average yield $(\mathrm{Q} / \mathrm{ha}$.) & Yield gap (Q/ha.) \\
\hline $\mathbf{1}$ & Paddy & 27 & 20 & $\mathbf{7}$ \\
\hline $\mathbf{2}$ & Wheat & 32 & 24 & $\mathbf{8}$ \\
\hline $\mathbf{3}$ & Maize & 19 & 13 & $\mathbf{6}$ \\
\hline $\mathbf{4}$ & Potato & 252 & 215 & $\mathbf{4}$ \\
\hline $\mathbf{5}$ & Mustard & 10 & 6 & $\mathbf{5}$ \\
\hline $\mathbf{6}$ & Arhar & $\mathbf{1 2}$ & $\mathbf{7}$ & \\
\hline
\end{tabular}


Table.2b Cost and income of agriculture

\begin{tabular}{|l|l|c|c|c|c|c|c|}
\hline \multirow{2}{*}{ S.No } & \multicolumn{1}{|c|}{ Particulars } & \multicolumn{2}{|c|}{ Paddy } & \multicolumn{2}{c|}{ Wheat } & \multicolumn{2}{c|}{ Potato } \\
\cline { 3 - 8 } & & B & N.B & B & N.B & B & N.B \\
\hline $\mathbf{1}$ & Production (Q/ha) & 27 & 20 & 32 & 24 & 252 & $\mathbf{2 1 5}$ \\
\hline $\mathbf{2}$ & Sale price (Rs/Q) & 560 & 560 & 580 & 580 & 280 & $\mathbf{2 8 0}$ \\
\hline $\mathbf{3}$ & Gross income (Rs/ha) & 15120 & 11760 & 18560 & 15080 & 70560 & $\mathbf{6 5 5 2 0}$ \\
\hline $\mathbf{4}$ & Total expenditure (Rs/ha) & 8500 & 8700 & 9500 & 9900 & 22000 & $\mathbf{2 3 0 0 0}$ \\
\hline $\mathbf{5}$ & Net returns (Rs/ha) & $\mathbf{6 6 2 0}$ & $\mathbf{2 5 0 0}$ & $\mathbf{9 0 6 0}$ & $\mathbf{4 0 2 0}$ & $\mathbf{4 8 5 6 0}$ & $\mathbf{3 7 2 0 0}$ \\
\hline
\end{tabular}

*B: Beneficiaries, N.B: Non-beneficiaries

Table.3 Yield of vegetable crops of respondents and the yield gap between respondents

\begin{tabular}{|l|l|c|c|c|}
\hline S.No & \multirow{2}{*}{ Vegetables } & Beneficiaries & Non-Beneficiaries & Difference \\
\cline { 3 - 5 } & & Average yield (Q/ha.) & Average yield (Q/ha.) & Yield gap (Q/ha.) \\
\hline $\mathbf{1}$ & Tomato & 248 & 212 & $\mathbf{3 6}$ \\
\hline $\mathbf{2}$ & Brinjal & 245 & 210 & $\mathbf{3 5}$ \\
\hline $\mathbf{3}$ & Onion & 160 & 120 & $\mathbf{4 0}$ \\
\hline $\mathbf{4}$ & Green Pea & $\mathbf{6 2}$ & $\mathbf{4 0}$ & $\mathbf{2 2}$ \\
\hline
\end{tabular}

Table.4 Comparative yield of milk and the milk sold in the market

\begin{tabular}{|c|c|c|c|c|}
\hline \multirow[t]{2}{*}{ S.No } & \multirow[t]{2}{*}{ Milch animals } & Beneficiaries & Non-Beneficiaries & Difference \\
\hline & & $\begin{array}{l}\text { Average production } \\
\text { (lit/day/animal) }\end{array}$ & $\begin{array}{c}\text { Average production } \\
\text { (lit/day/animal) }\end{array}$ & $\begin{array}{l}\text { Yield gap } \\
\text { (lit/day/animal) }\end{array}$ \\
\hline A & \multicolumn{4}{|l|}{ Cow } \\
\hline 1 & Local & 3.50 & 3.00 & 0.5 \\
\hline 2 & Cross & 4.80 & 3.60 & 1.2 \\
\hline B & \multicolumn{4}{|l|}{ Buffalo } \\
\hline 1 & Local & 5.20 & 4.80 & 0.4 \\
\hline 2 & Improved & 6.3 & 5.00 & 1.3 \\
\hline \multicolumn{2}{|c|}{ Milk sold against total production (\%) } & 63 & 48 & \\
\hline
\end{tabular}

The figures with respect to Green Pea in case of beneficiaries was $62 \mathrm{Q} /$ ha against $40 \mathrm{Q} / \mathrm{ha}$ in case of non-beneficiaries thus leading a yield gap of about $22 \mathrm{Q} / \mathrm{ha}$. It depicts that yield level in respect of vegetables in case of beneficiaries was comparatively much higher than non-beneficiaries which shows that the DASP intervention had a prominent impact of the production level.

\section{Impact of DASP interventions on Animal Husbandry}

An average production of milk for cows and buffaloes both local and cross bred among beneficiaries and non-beneficiaries were calculated besides the yield gaps (lit/day/animal) and milk sold against the total production were also estimated for the purpose of arriving at some impact conclusion on Animal Husbandry sector through DASP. The data on the same is presented under Table 4.

The figures given in the Table 4 with respect to yield of milk shows that the average yield of milk per animal per day with respect to cow (3.5 lit/day/local cow and 4.8 lit/day/ crossbreed cow) and buffalo (5.2 lit/day/local buffalo and 6.3 lit/day/ improved buffalo) in 
case of beneficiaries was higher than the average milk production in case of nonbeneficiaries, also the percentage of milk sold against the total milk production for beneficiaries was comparatively higher than non-beneficiaries. Therefore, it was concluded that DASP intervention with respect to Animal Husbandry had a significant impact.

The present study leads to the conclusion that the project intervention under DASP in respect of Agriculture \& Allied sectors has a remarkable impact on beneficiaries. The significant difference between beneficiaries and non-beneficiaries was observed in respect of different key performance indicators related with Agriculture and Allied sectors mainly because of the transfer of the demand driven, farmer-oriented, need based technologies and their adoption coupled with effective extension services and timely advisories which resulted in higher yields and income to the beneficiaries than nonbeneficiaries which were observed performing far below under the predetermined performance indictors thus reflecting urgent need to brought them under the ambit of such flagship programme to benefit the farmers at large.

\section{References}

Anonymous (2016) Agricultural Statistics at a Glance 2016,GoI, Ministry of Agriculture \& Farmers Welfare, Directorate of Economics and Statistics wing.

Guyau,-L (2004); Economic organization: an asset for world farmers, Paris, France: Assemblee Permanente des Chambresd' Agriculture, Chambers-d'Agriculture. (934): 9-30

Yokoyama,-S; Sakurai,-T, (2003), Potential of social capital for community development. Report of the APO, Tokyo, Japan: Asian Productivity Organization (APO), Potential-ofsocial-capital-for-communitydevelopment-Report-of-the-APOsurvey-and-symposium-on-redesigningintegrated-community-development 250-251.

\section{How to cite this article:}

Malik, H.A., B.N. Tripathi, Nusrat Jan, J.A. Quadri, Sabiha Ashraf and Naqash, F. 2019. Impact of Diversified Agriculture Support Project (DASP) on Beneficiaries and Nonbeneficiaries of District Allahabad (Uttar Pradesh), India. Int.J.Curr.Microbiol.App.Sci. 8(02): 2569-2576. doi: https://doi.org/10.20546/ijcmas.2019.802.299 